\title{
DIVERSITY OF PLANT VIRUSES IN THE EAST-ASIAN RUSSIA: 50 YEARS OF STUDYING
}

\section{R.V. GNUTOVA}

Institute of Biology and Soil Science, the Far East Branch of Russian Academy of Sciences, 159, Pr. 100-letiya Vladivostoka, Vladivostok, 690022 Russia, e-mail girina.vl@mail.ru, ibss@eastnet.febras.ru Supported by Presidium of the Far East Branch of Russian Academy of Sciences (2004-2008, 2010) Received April 23, 2013

\section{Abstract}

In ornamental plants, vegetables, fruits, berries, cereals and legumes the viral infections causes a decrease of productivity and yield quality, especially in the southern regions of agriculture in the Russian Far East where an infectious background is one of the highest. Besides, the viral infection leads to more impact from other phytopathogens, particularly under bacterial and fungal infections, and provokes degradation of varieties. Breeding varieties and hybrids resistant to viruses is now considered the most effective approach to antiviral plant protection. Therefore, the characteristic features of viruses are the key factors for plant protection strategy. For more than 50 years, in the Asian Russia more than 50 viruses have been found in agrocenoses of vegetables, cereals, legumes, ornamental plants, berries and potato plants, and also in biocenoses of wild plants and weeds. More than 10 of them have not been identified earlier not only in Far East and Siberia, but also in Russia. Basin on biological traits, physicochemical properties of viral polypeptides and nucleic acids, as well as antigenic characteristics of capsid proteins, a taxonomic status of the Asian Russian viral isolates has been identified, and their areal, pathogenicity and the impact have been studied. In Far East Russia, there have been revealed, described and identified the following viruses: Brome mosaic virus, Vicia unijuga mosaic virus, Alfalfa mosaic virus, Cucumber mosaic virus IA and IB East-Asian isolates, Soybean stunt virus, Tomato aspermy virus, Cauliflower mosaic virus Far-East Russian isolates, Dahlia mosaic virus, Radish mosaic virus type isolate, Red clover mottle virus, Arabis mosaic virus, Raspberry ringspot virus, Tobacco ringspot virus, Tomato ringspot virus, Potato leafrole virus, Barley yellow dwarf virus - PAV, Pea enation mosaic virus 1, Bean common mosaic virus, Bean yellow mosaic virus, Dahlia mild green mottle virus, Hippeastrum mosaic virus, Onion yellow dwarf virus, Potato virus A, Potato virus $Y$, Soybean mosaic virus, Tobacco etch virus, Tradescantia mosaic virus, Trifolium montanum (clover) mosaic virus, Turnip mosaic virus, Watermelon mosaic virus (WMV-W), Cereal (Oat) Russian pupation (pseudo-roset) virus, Northern cereal mosaic virus, Lily symptomless virus, Potato virus $M$, Potato virus $S$, Vicia pseudorobus mosaic virus, Hydrangea ringspot virus, Plantago asiatica mosaic virus, Potato aucuba mosaic virus, Potato virus X, White clover mosaic virus, Tobacco necrosis virus, Rice stripe virus, Tobacco rattle virus, Tobacco mosaic virus, Tomato mosaic virus, Cucumber green mottle mosaic virus, Barley stripe mosaic virus, Rice mottle virus, Grapevine plum line virus, Pea streak virus, Potato yellow dwarf virus, Carnation ringspot dianthovirus, Carnation mottle virus. A few of them (marked as ordinary typed) are not still registered and entered into the list of International Committee on Taxonomy of Viruses (http://www.ncbi.nlm.nih.gov/ICTVdb/ICTVdB/). Using routine and molecular methods, the isolates were attributed to 18 genera from 10 families of 87 genera and 20 families described presently. Considering distance of Far East from the Central Russia, specific ecological factors, the local climate and unstable weather, a strategy for phytomonitoring of plant viruses has been worked out. In the southern and central zones, the most attention was paid to viruses on rice and soybean plants. The phytomonitoring of potato, vegetable plants and other crops was carried out all over the Asian Russia in both field conditions and greenhouses.

Keywords: plant viruses, methods of identification, taxonomy, East-Asian territory of Russia.

Viruses, the pathogenic agents, cause a significant decrease of plant productivity, especially in the Russian Far East where the levels of infections are rather high. Viral infection leads to worse exterior parameters and decreased quality of ornamental, fruit and berry plants, vegetables, grain and legume crops. Besides, viral infection contributes to invasions by other pathogens, such as bacteria and fungi, and also can provoke a degeneration of valuable varieties. Nowadays, the breeding of tolerant varieties and hybrids are considered the most

Taxonomy of viruses from Asian territory of Russia (28) 


\begin{tabular}{|c|c|c|}
\hline Genome, order, family & Genus & Species \\
\hline $\begin{array}{l}\text { ssRNA }(+) \\
\text { Bromoviridae }\end{array}$ & $\begin{array}{l}\text { Bromovirus } \\
\text { Alfamovirus } \\
\text { Cucumovirus }\end{array}$ & $\begin{array}{l}\text { Brome mosaic virus } \\
\text { Vicia unijuga mosaic virus }{ }^{1} \\
\text { Alfalfa mosaic virus } \\
\text { Cucumber mosaic virus IA and IB East-Asian isolates } \\
\text { Soybean stunt virus }{ }^{1} \\
\text { Tomato aspermy virus }\end{array}$ \\
\hline $\begin{array}{l}\text { dsDNA-RT } \\
\text { Caulimoviridae }\end{array}$ & Caulimovirus & $\begin{array}{l}\text { Cauliflower mosaic virus Far-East Russian isolates } \\
\text { Dahlia mosaic virus }\end{array}$ \\
\hline $\begin{array}{l}\text { ssRNA }(+) \\
\text { Pecornovirales } \\
\text { Comoviridae }\end{array}$ & $\begin{array}{l}\text { Comovirus } \\
\text { Nepovirus }\end{array}$ & $\begin{array}{l}\text { Radish mosaic virus type isolate } \\
\text { Red clover mottle virus } \\
\text { Arabis mosaic virus } \\
\text { Raspberry ringspot virus } \\
\text { Tobacco ringspot virus } \\
\text { Tomato ringspot virus }\end{array}$ \\
\hline $\begin{array}{l}\text { ssRNA }(+) \\
\text { Luteoviridae }\end{array}$ & $\begin{array}{l}\text { Polerovirus } \\
\text { Luteovirus } \\
\text { Enamovirus }\end{array}$ & $\begin{array}{l}\text { Potato leafrole virus } \\
\text { Barley yellow dwarf virus }-P A V \\
\text { Pea enation mosaic virus } 1\end{array}$ \\
\hline $\begin{array}{l}\text { ssRNA(+) } \\
\text { Potyviridae }\end{array}$ & Potyvirus & $\begin{array}{l}\text { Bean common mosaic virus } \\
\text { Bean yellow mosaic virus } \\
\text { Dahlia mild green mottle virus } 1 \\
\text { Hippeastrum mosaic virus } \\
\text { Onion yellow dwarf virus } \\
\text { Potato virus } A \\
\text { Potato virus } Y \\
\text { Soybean mosaic virus } \\
\text { Tobacco etch virus } \\
\text { Tradescantia mosaic virus } \\
\text { Trifolium montanum (clover) mosaic virus }{ }^{1} \\
\text { Turnip mosaic virus } \\
\text { Watermelon mosaic virus }(W M W-W)\end{array}$ \\
\hline $\begin{array}{l}\text { ssRNA(-) } \\
\text { Rhabdoviridae }\end{array}$ & Cytorhabdovirus & $\begin{array}{l}\text { Cereal (Oat) Russian pupation (pseudo-roset) virus }{ }^{1} \\
\text { Northern cereal mosaic virus }\end{array}$ \\
\hline $\begin{array}{l}\text { ssRNA(+) } \\
\text { Tymovirales } \\
\text { Betaflexiviridae }\end{array}$ & Carlavirus & $\begin{array}{l}\text { Lily symptomless virus } \\
\text { Potato virus } M \\
\text { Potato virus } S \\
\text { Vicia pseudorobus mosaic virus } 1\end{array}$ \\
\hline $\begin{array}{l}\text { ssRNA(+) } \\
\text { Tymovirales } \\
\text { Alphaflexiviridae }\end{array}$ & Potexvirus & $\begin{array}{l}\text { Hydrangea ringspot virus } \\
\text { Plantago asiatica mosaic virus } \\
\text { Potato aucuba mosaic virus } \\
\text { Potato virus } X \\
\text { White clover mosaic virus }\end{array}$ \\
\hline $\begin{array}{l}\text { ssRNA }(+) \\
\text { Tombusviridae }\end{array}$ & Necrovirus & Tobacco necrosis virus \\
\hline $\begin{array}{l}\text { ssRNA(+) } \\
\text { «floating» genus }\end{array}$ & Tenuivirus & Rice stripe virus \\
\hline $\begin{array}{l}\text { ssRNA }(+) \\
\text { Virgaviridae }\end{array}$ & $\begin{array}{l}\text { Tobravirus } \\
\text { Tobamovirus } \\
\text { Hordievirus }\end{array}$ & $\begin{array}{l}\text { Tobacco rattle virus } \\
\text { Tobacco mosaic virus } \\
\text { Tomato mosaic virus } \\
\text { Cucumber green mottle mosaic virus } \\
\text { Barley stripe mosaic virus }\end{array}$ \\
\hline $\begin{array}{l}\text { ssRNA(+) } \\
\text { Not classified viruses }\end{array}$ & & $\begin{array}{l}\text { Rice mottle virus } \\
\text { Grapevine plum line virus } \\
\text { Pea streak virus } \\
\text { Potato yellow dwarf virus } \\
\text { Carnation ringspot dianthovirus } \\
\text { Carnation mottle virus }\end{array}$ \\
\hline
\end{tabular}

Comments. 1 - viruses not registered in the List of International Committee on Taxonomy of Viruses - ICTV, http://www.ncbi.nlm.nih.gov/ICTVdb/ICTVdB/).

effective approach to antiviral defense. This is why the characteristic features of the viruses become a key factor to determine a strategy for plant protection from these pathogens. In many European countries the creation of varieties tolerant to viral diseases, and drafting adaptive agroecosystems benefit the economy and allow to improve environment. To grow tolerant varieties and obtain the high yield, there is no need to apply high doses of pesticides. 
First investigations of phytopathogenic viruses in the Far East are associated with the study of potato diseases. The vegetative mode of potato propagation resulted in fast accumulation of the viruses during several vegetation seasons, leading to degradation of the crop. Yield losses made 10-50\%, and the tuber quality was deteriorated, in particular, starch and vitamin $\mathrm{C}$ concentration decreased. It was important not only to study a severity and pathogenicity of mono- and mixed infections, but also to obtain healthy seed material and cultivate the varieties tolerant to viral infection. To start with, the most severe and spread potato viruses such as Potato virus $X$ (PVX), Potato leafroll virus, Potato virus $Y$ and Potato virus A (PVY and PVA), Potato aucuba mosaic virus, Potato virus $M$ and Potato virus $S$ (PVM and PVS) (Table) have been detected. Further, the list lengthened, including Tobacco rattle tobravirus, Alfalfa mosaic virus, Tobacco mosaic virus (TMV), Cucumber mosaic virus (CMV). A significant biodiversity of PVX, PVY, PVM and PVS species was characteristic $(1,2)$. By the beginning of XXI century, a virus-free potato seed reproduction based on the recovery of varieties and accelerated propagation of the initial seed material in the conditions precluding re-infection, allows to solve most problems of potato cultivation in the region due to application the apical meristem method and culling infected plants in the tests with antiviral serum $(3,4)$. After 1990, as new pathogens, viroids and mycoplasmas, were revealed, their investigation and the development of protective measures became actual. Particularly, in potato, Potato spindle tuber viroid (5) and Potato leaf edge yellowing virus (6) were described.

In vegetables cultures, mainly of Brassicaceae Burnett., Solanaceae Juss., Cucurbitaceae Juss., Liliaceae Juss., Apiaceae Lindl., Chenopodaceae Vent. and Fabaceae Lindl. families, the identified viruses formed the most numerous group of more than 20 species (7). The most frequent viral infections were registered on plants of Cucurbitaceae family, e.g. zucchini, pumpkin, melon, cucumber, squash, watermelon et al., Solanaceae family, e.g. tomatoes, eggplants, peppers et al., Brassicaceae family, e.g. different cabbages, cauliflower, radish, loba, daikon et al., and Fabaceae family, e.g. vegetable beans, peas vegetable, beans faba et al.. Phytomonitoring in 2000-2013 showed the CMV and TMV being the most widespread and harmful in Cucurbitaceae and Solanaceae plants, respectively. They both, the CMV and TMV, demonstrate a significant biodiversity, since over 20-30 TMV isolates and over 40 CMV isolates were described in drag, ornamental and other plants only in the Far East (8).

For CMV, a tripartite $(+)$ RNA genome is characteristic, being a reason to study a genetic variability of its numerous Far East isolates. In Chabarovskii krai, in the Amur River basin, they infected tomato Lycopersicon esculentum L., pepper Capsicum annuum L., pumpkin Cucurbita maxima spp., melon Cucurbita melo spp. and cucumber Cucumis sativus spp. plants, in the Primorskii krai the infections were mostly found on tomato, cucumber, pepper, sometimes on watermelon, zucchini, squash, eggplant and pumpkin $(9,10)$. CMV also was identified on Kamchatka. No CMV infections were found in cabbage, horseradish, lettuce and parsley. Rather often the mixed infections with TMV could be observed resulting in significant yield losses that could sometimes reach 80 to $100 \%$. The obtained data for the Far East isolates were the same as for a conventional CMV strain (11). The isolates were easy transmitted mechanically and by aphids, but not by mean of seeds. According to the antigenic specificity of capsid proteins we identified the CMV isolates as a Far East serotype, and basing on PCR they were assigned to the IB subgroup of CMV East Asian isolates, or the vegetable isolate of Khabarovs, and IA isolates, or the ornamental isolates of Primorskii krai (12). It should be noted that in recent decades there were constant attempts to offer a rational classification of CMV isolates. First, basing on the biological characteristics they were divided into two groups, I and II, that has 
been confirmed by molecular methods. Then, two groups, the Fny (I) and Q (II), varing on nucleotide sequences at 60-70\%, were formed of CMV population. Further, two subgroups, the IB and IA (the East Asian and the most common world isolates, respectively) were identified in I group.

Recently the genetic variability of 7 the most unique East Asian TMV isolates, infecting vegetables is under consideration to clarify their belonging to genus Tobamovirus (13). Earlier the Tobamovirus genus was not assigned to any known family, and only in 2009, together with other five «floating» genera, it was assigned to Virgaviridae family. RNA-sequencing showed the tight similarity of tobamoviruses comparing to other genera of the family. Thus, the International Committee on Taxonomy of Viruses, recommended to revise attributing known and newly isolated tobamoviruses to clarify their taxonomy according to the genome sequences (http://www.ncbi.nlm.nih.gov/ICTVdb/ICTVdB/). It was suggested that in case the homology is below $10 \%$, the isolates are the strains of the same species but not different species. In the course of comparative phylogenetic analysis of gene sequences in isolated obtained in our investigations, and TMV from GenBank (http://www.ncbi.nlm.nih.gov/nuccore/), the virus envelope protein (VEP) gene of $480 \mathrm{bp}$ was identified in the eggplant isolate from Priamur'e (TMV-eggA) and in North Korean isolate (TMV-tNK) found on tomato plants in greenhouses (Institute of Experimental Biology, Academia of Science, DPRK, Pyangyang) and used as a control. With respect to biological and antigenic properties TMV-eggA was assigned to the tomato group, and TMV-tNK was assigned to the tobacco group. These isolates demonstrated high similarity to TMV and were less similar to Rehmannia mosaic virus (RMV) and Tomato mosaic virus (ToMV). Genome sequences of TMV-tNK and most TMV isolates demonstrated 97-99\% homology. As to amino acid composition of VEP, there was 94-95\% homology to RMV and only 83-85\% homology to ToMV. To standard isolate TMV U1, TMV-eggA is $95 \%$ similar on the VEP amino acid sequence and $89 \%$ similar on the genome sequence. The highest similarity to Mx isolates from Mexico (96 and $96 \%$, respectively), pet-TW from Taiwan (97 and $96 \%$, respectively), Ohio V from USA ( 99 and $98 \%$, respectively) was indicated allowing them to from a cluster. To them, TMV-eggA also demonstrates high degree of identity, e.g. $99 \%$ homology of VEP gene to Ohio V, indicating the probability of common origin. Wherein, there was $90 \%$ similarity on VEP gene and $96 \%$ similarity on VEP between Ohio V and TMV U1, and the same data were obtained for TMV-eggA. Besides, eggplant Far East Russian isolates, similar to other isolates from its cluster, clearly differed from other TMV isolates due to extreme number of silent mutations. Comparing to TMV U1, only 5 of 50 point mutations in VPE resulted in the amino acid replacement. In further investigations of East Asian TMV isolates, it should be found out whether it is an adaptation to a group of test plants, or this phenomenon resulted from long geographic isolation from the main TMV population. According to our data, the genetic diversity of nucleotide sequences in most TMV isolates is very low (up to $6 \%$ ), thus, the $11 \%$ divergence seems to be rather significant. Ohio V is the only isolate with reported sequence, while the others are only deposited in GenBank. The data obtained for genome of eggplant Far East Russian isolates could be helpful to clarify the taxonomy of TMV from this cluster.

On brassica vegetable plants and dahlias the DNA Cauliflower mosaic virus (CaMV) and Dahlia mosaic virus were found. Molecular study of eight CaMV isolates from daikon, cauliflower, cabbage, radish pants suggests them to be the Russian Far East population different from foreign isolates deposited in GenBank (14). To discuss their relationships in more detail, the genome sequencing should be completed.

According to data obtained, the members of Potyvirus genus of Poty- 
viridae family are mostly distributed on vegetable crops (10). In Primor'e region on pepper plant the Tobacco etch virus was found for the first time in Russia. A Siberian isolate of Onion yellow dwarf virus detected in Novosibirskaya and Irkutskaya provinces has been studied. Another potyviruse, Bean yellow mosaic virus (BYMV) before recent time infected few plants of Fabacea family, such as soybean, red clover, pea, bean. To date, BYMV is frequently detected in biocenosis on different clover species, but unexpectedly for the first time in Russia it was also found on Cucurbitaceae vegetable plants. One more virus not found in Russia before, the Watermelon mosaic virus (WMV) was also isolated, and two its pathotypes, WMV-P and WMV-A with pawpaw and watermelon as test plants, respectively, are currently described. The Far East WMV isolate according to its properties could be assigned to WMV-A pathotype. It is extracted from squash and watermelon in Primorskii krai, and from squash on Sakhalin. In vegetable crops, Alfalfa mosaic virus, Radish mosaic virus, Turnip mosaic virus, Tomato mosaic virus, PVY, White clover mosaic virus, PVX, TMV, Cucumber green mottle mosaic virus and PVS have been also described.

The ornamental plants, e.g. petunia, hollyhock, snapdragon, the last being described as a CMV test plant for the firs time, delphinium, ficus, faskheda, dahlias, orchids were mostly infected by CMV, while, according to publications, in southern countries the orchids are rarely infected by CMV (15). On dahlia, apart from CMV and Dahlia DNA mosaic virus, we detected Dahlia mild green mottle virus which was not observed until recent time either as a member of Potyvirus genus, or as a Dahlia ssp. pathogen (16). Of Potyvirus on dahlia, only Beet mosaic virus has been earlier reported (17). For Lily symptomless virus and Tulipa virus 1 the host plant range was mainly restricted by the species of Liliaceae family. The Tradescantia mosaic virus, a new potyvirus in Russia and in the Russian Far East, particularly, was also identified. This virus initially infected only Commelinaceae plants. A recent comparison of our results and databases (18) evidences that, according to ICTV, this Far East isolate is to be identified as Tradescantia mosaic virus from Potyvirus.

Daffodils were infected by Tobacco necrosis virus and the two TMV original strains. PVX was isolated from petunias, henbane and chrysanthemums, $H y$ drangea ringspot virus was found on hydrangea, Carnation ringspot dianthovirus was identified on carnation, commonly mixed with Carnation mottle virus, BYMV was isolated from gladiolus, Japanese aucuba, iris and Tigridia pavonia (28). Tomato aspermy virus was detected in Primorskii krai and Khabarovskii krai on chrysanthemums in greenhouses (8).

Unfortunately, with accordance to ICTV regulations, only four viruses of those infecting grain crops in the Russian Far East can be registered by the ICTV rules, but in fact the range of these viruses is much wider. They are Barley stripe mosaic virus from barley and whet plants in Primorskii krai, Brome mosaic virus first found in Amur Province on cultivated and wild cereals (8), and two cytorhabdoviruses, Northern cereal mosaic virus (NCMV) not detected previously in Russia, and Cereal (Oat) Russian pupation (pseudo-roset) virus (CRPV). CRPV may be considered the exclusive Russian virus as it is found only in Russia, similar to Russian winter wheat mosaic virus characteristic for the European Russia. Both properties of these two rhabdoviruses and biology of their the only vector, Laodelphax striatteleus F., were studied (19). Areas of these viruses differ (19), with CRPV frequently found in Siberia, and NCMV detected in the Amur River Basin in Primorskii krai, Khabarovskii krai and Chitinskaya Province. Due to the industrial cultivation of crops, NCMV is the most spread in the South of the Amur region, where the epiphytotics often cause a significant losses of yields. Natural NCMV circulation is related to biological peculiarities of its vector, L. striatteleus F., and crop loses depend on effectiveness of L. stri- 
atteleus as a source of infection and NCMV number.

In rice, Rice stripe virus and Rice mottle virus have been found (8).

The southern Far East is the main Russian territory for soybean cultivation, thus, in the region the undiverted attention is paid to viral patholodies. According to detected symptoms, the viruses infecting Fabacea plants can be divided into the groups with stringent and wide-range specificity. Those from the first group demonstrate a restricted range of host plants, while those from the second one are characterized by high-effective transmittion of viruses in different ways, including infected seeds, and a dependence on natural foci of infection, e.g. perennial weeds and cultivated plants). In the world, more than 30 viruses infecting legumes have been currently described; of them 10 viruses have been studied in the Russian Far East. White clover mosaic virus was isolated from pea, red and white clover plants in Primor'e and on Sakhalin. For Pea enation mosaic virus 1 found on pea plants in Primor'e, a narrow range of host plants, the Fabacea species mainly, is characteristic (20). Bean common mosaic virus (BCMV) was firstly identified in bean plants. Its host plants are the members of Fabacea genera, Phaseolus, Pisum, Trifolium, Vicia, Vigna mainly. BCMV is a non-persistant virus transmitted mechanically and by different aphids, and the high level of seed transmission is also characteristic. Due to comparative study of biological and antigenic characteristics of three BCMV isolates from the Russian Far Eats, China and North Korea, a lot of their similarities has bee found out (8). BCMV was isolated from pea and bean plants. The bean isolate from Primor'e infected legumes only, and could be easy transmitted mechanically and by aphids, also low seed transmission was detected depending on the plant variety and species. There is a single report about Red clover mottle virus found in the Russian Far East on pea plants (21). Tobacco ringspot virus isolated from soybean plants can be easy transmitted to Nicotiana tabacum L., pea, cowpeas, and through seed infection. Besides, the virus was extremely sensitive to external conditions, and at $28-30{ }^{\circ} \mathrm{C}$ no visible symptoms of infection could be detected (20).

For soybean in Primorskii krai and Khavarovskii krai, and later in Amur Rovince, the Soybean mosaic virus (SMV) is the most common and harmful. Its host plant range is rather limited, and for the long time the virus was considered to infect Glycine $\max (\mathrm{L}$.) Merr. only. To date there are described more than 30 plant species that can be infected, and for 10 of them a local reaction to SMV infection or latent infection are characteristic. SMV is easy transmitted via inoculation and through seed infection being commonly occurred. More than 20 aphids can transmit SMV. As to symptoms of infection, there are SMV of strong, low and moderate pathogenicity. Low-pathogenic SMV strain is spread on soybean crops in Amur Rovince. Nevertheless, soybean varieties are mostly infected by the strain of moderate pathogenicity similar to Japanise strain B. The high-pathogenic strain caused yellowing and necrotisation in leaves and apexes in the plants, they often died or were unable to yield production. SMV also infected some bean species.

Soybean stunt virus (SSV) was isolated in Amur Region from soybean plants (20). It can be easy transmitted under juice inoculation, by different aphids and via seeds. Soybean plants are its natural host. In infected plants a ring-like pigmentation of seed coat can be observed. The experimental host plant range is wide including plants of Amaranthaceae, Compositae, Chenopodiaceae, Fabaceae, Solanaceae, Polygnaceae families, etc. The virus is spread in the South-East Asia, particularly in China, Indonesia, Japan, etc. It is not yet included into the list of ICTV, but, considering properties, we assigned SBS to Cucumovirus genus of Bromoviridae family.

The viruses that affect berry crops are poorly studied. On raspberries and 
currants the Tomato ringspot virus, Arabis mosaic virus, Raspberry ringspot virus of Nepovirus genus were identified (8). The same investigators also found CMV in berry crops.

Due to monitoring both agro- and biocoenoses in the Far East, not only infected plants, but cultivated vegetables, ornamentals, legumes, potato plants, natural herbaceous plants (e.g. different kinds of clover, plantain, etc.) were shown to be a reservation of viral infection. The pathogens were also detected on weeds and wild plants. They are White clover mosaic virus, Red clover mottle virus, Plantago asiatica mosaic virus from Sakhakin and Primor'e regions, PVX, TMV on plantain and BYMV on white clover from Sakhalin region, etc. In biocenoses, some viruses of legumes, namely Vicia pseudorobus mosaic virus, Vicia unijuga mosaic virus and Trifolium montanum (clover) mosaic virus, were first studied (22). Alfalfa mosaic virus was detected in red clover. Recently the BYMV frequently occurs in different clover species. For BYMV isolates derived from Trifolium montanum of Primirskii krai and Khabarovsk region, the narrow rang of host plants was revealed comparing to that of standard strain.

Immunochemical study of capsid proteins, together with biological features of the viruses, were the key for identification of the Far East isolates (1). The methods for preparative isolation were developed and precise immunochemical tests used to examine the antigenic relationships among the species of a genus. For virus-free plant cultivation the immunodiagnostics was used. Furthermore, the biological features of vectors, the ahids and leafhoppers, and the mode of natural and experimental tramsmission of viruses by vectors and via seeds were studied, etc. The viroses of wild plants and weeds were revealed, and the biophysical methods used to obtain the seeds which were free of viruses, etc. (23).

Due to molecular methods, the results of identification were confirmed, and a genetic variability of some Far East isolates (e.g. Cauliflower mosaic virus Far-East Russian isolates, CMV, TMV, etc.) studied. Also a phylogenetic analysis of the isolates has been carried out using data from GenBank. At the end of 1990s, almost 40 viruses were identified, while much more isolates and strains were studied. Described viruses were assigned to 16 genera and 5 families $(1,24)$. A decade later, the number of described viruses increased, and they were assigned to 17 genera and 8 families (8). The isolates derived from the Asian Russia are the member of 18 genera and 10 families (see Table.) of 87 genera and 20 families of plant viruses currently known (25). In the table there are some viruses the properties of which are not yet understood, namely Grapevine plum line virus, Pea streak virus, Potato yellow dwarf virus (26), Carnation ringspot dianthovirus, Carnation mottle virus и др.

In virology for the last 20 years the changes in taxonomy are much more fundamental comparing to other fields of biology. Unlike the viruses of vertebral animals and microorganisms, plant viruses were not associated with specific taxons, being mostly assigned to groups but not the genera. Recently developed taxonomy of viruses includes the hierarchical levels, i.e. the order, family, genus, species (virus). Due to extra data about viral genomes together with common tests used, more correct identification of viruses is possible, and new genera and families of plant viruses appear. Comparison of our data and the results reported by $\operatorname{ICTV}(27,28)$, allowed to suggest the taxonomy of plant viruses of the Russian Far East region according to the concepts accepted in modern virology. Nevertheless, in the next ICTV report (25) there were sufficient amendments. In particular, new genera and their families were reported. These changes have also affected the Russian Asian isolates (see Table). Thus, the members of Tobamovirus genus are included in new family Virgaviridae. Flexiviridae family is turned into three new ones, of which two, Alphaflexiviridae and Betaflexiviridae, were 
replenished with new genera, etc. The most impressive data concerning a relationship among viruses of a species are obtained by molecular methods. Nevertheless, there are some mismatches between systematics based on classical and molecular approaches, therefore the criteria must be suggested to solve the contradictions. Certainly, during the coming years, in the taxonomy of viruses dramatic changes have to occur since the characteristic of many viruses is still based on incomplete information about their genome.

Thus, the accumulated phytovirological data reflect the level of investigation in the Asian Russia. Doubtlessly the number of plant viruses detected in this region will increase.

Contemporary approaches to estimation of virological situation and development of effective practical technologies were the goals of fundamental and applied research conducted since 2004 in Far East Institute of Biology and Soils (RAS) and a number of regional agricultural institutes (Primirskii institute, Far East institute, Sakhalin institute. Kamchatskii institute). Taking into account the regional peculiarities, such as remoteness from the central regions of Russia and the instability of the weather conditions, the regional strategy for agricultural development was formulated. According to the strategy, the potato and vegetable crops could be grown throughout, the soybean production was located in Primorskii krai and Khabarovskii krai, grain crops production was located in Amurskaya Province, Primorskii krai was the area of rice production, etc. Long-term investigations showed the role of treatment with chemicals to control the number of insects that serve as virus transmitters, but breeding tolerant varieties and hybrids is the most effective. During evolution the plants formed different defense mechanisms to prevent invasion and development of infection. There are host plants not infected by viruses, and also host plants with different tolerance ot infection. Non host resistance, being not individual, can be manifested in a species, if all the members of a species loss the factor necessary for successful infection development, or this factor is changed. Due to mutation the virus can obtain the ability to infect plants beyond the initial host rang, but loss the ability to infect its common hosts. Non host resistance mechanisms are not still found out (29). All these and many other aspects are important to create tolerant varieties.

So, in coenoses of the Russian Far East and Siberian regions, the wideranged experiments have been conducted for about 50 years to detect and identify viruses, to study their reservoirs and ways of transmission, a relationships in associations, plant tolerance to viral infection, etc. Till recent time, such comprehensive observations have been carried out in the Far East only. The route survey for the length, the territory, and the diversity of climatic zones could be considered unique. Nevertheless, the Asian Russia, in particular Siberia, Magadanskaya Province, Sakhalin island, Kamchatka, still remains insufficiently known according to species composition, prevalence and severity of viruses. These investigations seem to be relevant, as the taxonomy of viruses is one of the most dynamically developing and permanently changing field of virology. Due to molecular methods of sequencing genome and phylogenetic study of viral isolated derived from different sources, both fundamental and applied research became more effective.

\section{R E F E R E N C ES}

1. G nutova R.V. Serologiya i immunokhimiya virusov rastenii [Serology and immunochemistry of plant viruses]. Moscow, 1993.

2. Ro m a n ova S.A. V sbornike: Stanovlenie i razvitie fitovirusologii na Dal'nem Vostoke Rossii. [In: Phytovirology in the Russian Far East]. Vladivostok, 2002: 175-192.

3. G nut ov a R.V. V sbornike: Sostoyanie i perspektivy razvitiya selektsii i semenovodstva kartofe- 
lya na Dal'nem Vostoke [In: Recent state of potato breeding and seed reproduction in the Russian Far East]. Vladivostok, 2010: 138-150.

4. D'yak on ov K.P., P is etskaya N.F. V sbornike: Stanovlenie $i$ razvitie fitovirusologicheskikh issledovanii na Dal'nem Vostoke Rossii [In: Phytovirology in the Russian Far East]. Vladivostok, 2002: 203-212.

5. G nutova R.V., M o z h a e va K.A. Izvestiya TSKHA, 2010, 2: 35-43.

6. R e if m a n V.G. V sbornike: Vozbuditeli boleznei sel'skokhozyaistvennykh rastenii [In: Pathogens of agricultural plants]. Moscow, 1980: 293-315.

7. G nutova R.V., Z olotareva E.V. Bolezni ovoshchnykh kul'tur i kartofelya na Dal'nem Vostoke Rossii [Diseases of vegetable crops and potato in the Russian Far East]. Vladivostok, 2011.

8. G nut ova R.V. Taksonomiya virusov rastenii Dal'nego Vostoka [Taxonomy of plant viruses of the Far East]. Vladivostok, 2009.

9. Tolk a c h V.F., G n u t ova R.V. Zashchita i karantin rastenii, 2011, 7: 24-26.

10. G nut ov a R.V. Izvestiya TSKHA, 2013, 5: 321-340.

11. Virus Taxonomy. Seventh Report of ICTV /M.H.V. Van Regenmortel, C.M. Fauquet, D.H.L. Bishop et al. (eds.). NY, San Diego, Acad. Press, 2000.

12. G nut ova R.V., N e s m e lov I.B. Materialy Mezhdunarodnoi konferentsii «Selektsiya $i$ genetika sel'skokhozyaistvennykh rastenii: traditsii i perspektivy» [Proc. Int. Conf. «Breeding and Genetics of Agricultural Plants: Traditions and Prospects»]. Odessa, 2012: 327-328.

13. S i n y a v sk y a A.A., G n u t ov a R.V. Tezisy VII Mezhdunaridnoi konferentsii «Bioresursy $i$ virusy». [Proc. VII Int. Conf. «Bioresourses and Viruses»]. Kiev, 2013: 88.

14. B o g u n o v Yu.V., G n u t o v a R.V. Vestnik KNU (Kiev), seriya biologicheskaya, 2005, 44: 10-12.

15. Tolk a ch V.F., G nut o va R.V. Izvestiya TSKHA, 2007, 4: 165-173.

16. Tolkach V.Fh., Gnutova R.V. New Potyvirus plants genus Dahlia spp. Proc. VI Int. Conf. «Bioresources and Viruses». Kiev, 2010: 102.

17. Gnutova R.V., Tolkach V.F., Shelekhova O.M. Rastitel'nyi mir aziatskoi Rossii (Novosibirsk), 2011, 1: 91-98.

18. CTBdB - The Universal Virus Database. Index to ICTBdB virus descriptions. Version 4. NY, USA, 2006.

19. M a m a e v P.Yu. Biologiya virusov (severnoi) mozaiki i zakuklivaniya zlakov, ikh perenoschika temnoi tsikadki Laodelphax striatteleus F. Avtoreferat kandidatskoi dissertatsii [Biological features of cereal mosaic and pupation viruses and their vector, Laodelphax striatteleus $\mathrm{F}$. $\mathrm{PhD}$ Thesis]. Vladivostok, 1998.

20. Poliva n ova T.A. V sbornike: Vozbuditeli boleznei sel'skokhozyaistvennykh rastenii Dal'nego Vostoka [In: Pathogens of agricultural plants in the Far East]. Moscow, 1980: 51-84.

21. K r y lov A.V. Virusy rastenii Dal'nego Vostoka [Plant viruses of the Far East]. Moscow, 1992.

22 . Ko st in V.D. Virozy dikorastushchikh rastenii Dal'nego Vostoka Rossii [Viroses of wild plants in the Far East]. Vladivostok, 2005.

23. G n u tov a R.V. Vestnik DVO RAN, 2007, 6: 34-41.

24. Tol k a ch V.Fh., G n u t o v a R.V. Taxonomy of phytopathogenic viruses identified in the Russian Far East. Arch. Phytopathol. Plant Protect., 2000, 33: 187-205 (doi: 10.1080/03235400009383345).

25. Virus taxonomy. Classification and nomenclature of Viruses. Ninth Report of the International Committee on Taxonomy of viruses. Part I-IV /A.M.G. King, M.J. Adams, E.B. Carstens et al. (eds.). Elsevier Academic Press, Amsterdam, Boston, Heidelberg, London, NY, Oxford, Paris, San Diego, San Francisco, Singapore, Sidney, Tokyo, 2012.

26. Reifman V.G., Krulov A.V. Viruses affected on main crops and ornamental plants in Russia (Far East). In: Plant viruses in Asia. Yogyakarta, Indonesia, 1998: 986-989.

27. Virus Taxonomy. Eighth Report of ICTV /M.C. Fauguet, M.A. Mayo, U.M.J. Desselberger et al. (eds). Stat Louis, Danforth Sci. Centre. Univ. Missouri, Acad. Press, 2005.

28. G n u t o va R.V. Uspekhi sovremennoi biologii, 2011, 131(6): 563-577.

29. M a li n o v s k i i V.I. Mekhanizmy ustoichivosti rastenii $k$ virusam [Mechanisms of plant tolerance to viruses]. Vladivostok, 2010. 